SFB

Productivity and distribution effects of codetermination in an efficient bargaining model

Kornelius Kraft

$$
\text { Nr. 38/2015 }
$$
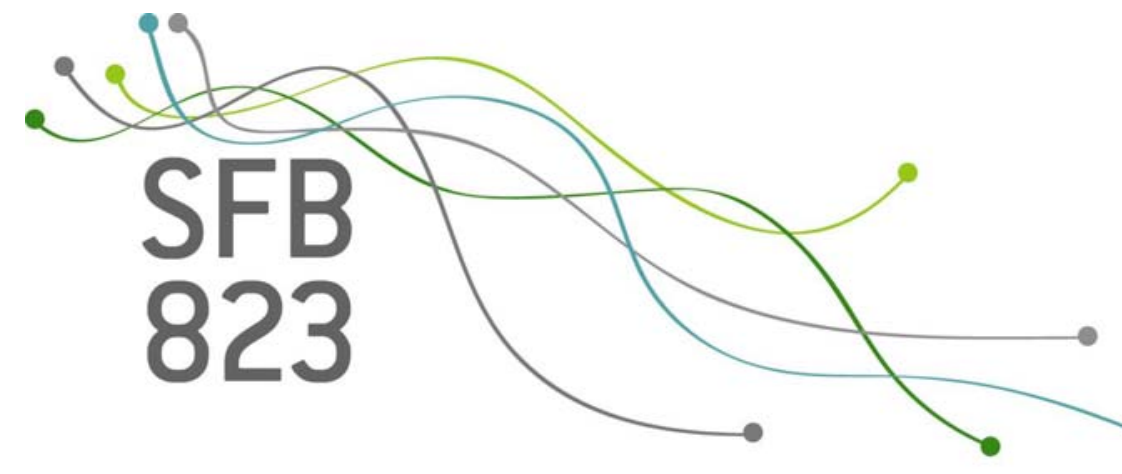



\title{
Productivity and Distribution Effects of Codetermination in an Efficient Bargaining Model
}

\section{Kornelius Kraft*}

September 2015

\begin{abstract}
Codetermination can be regarded as an exogenously determined intervention which possibly affects efficiency of production and bargaining power of labor. Based on a model which covers efficient bargaining as well as employment bargaining a simple equation is derived which is suited to empirical testing. The empirical test is based on German data and includes years before and after the extension of German codetermination law in 1976. The estimates determine productivity of labor and relative bargaining power of capital and labor. It turns out that codetermination does not reduce productivity, but leads to an increase in workers' bargaining power by about 7.4-7.9 percent.
\end{abstract}

JEL classification: L22, L23, J52, J53

Keywords: Codetermination, productivity, wage-bill share, bargaining

* TU Dortmund, Faculty of Economics, Business and Social Science, Vogelpothsweg 87, D-44221 Dortmund, Phone: (+49)231/755-3155, ZEW Mannheim and IZA Bonn, kornelius.kraft@tu-dortmund.de.

Financial support by the Deutsche Forschungsgemeinschaft (SFB 823,"Statistical modelling of nonlinear dynamic processes”) is gratefully acknowledged. 


\section{Introduction}

Labor markets are in all developed countries characterized by regulation through laws and institutions (Botero et al. 2004). These state interventions include labor law, collective bargaining laws as well as institutions, and social security regulation like unemployment benefits. Perotti and Thadden (2006) note that labor market institutions like corporate governance structure are shaped by political decisions and these decisions in turn are influenced by interests of the voters. Once established, corporate governance institutions affect decision making and determine (positively or negatively) rent creation as well as distribution. The topic of this contribution is the impact of a politically mandated change in corporate governance in Germany, namely codetermination, on productive efficiency of firms and the distribution of rents.

Bargaining between labor and capital is the topic of many articles on labor economics ${ }^{1}$. The bargaining power of labor is among other factors determined by the legal framework. In Germany legislation has granted specific rights to labor on plant (Works Constitution Act) and company level (Codetermination Act). Codetermination is realized by equal representation of worker representatives on supervisory boards ${ }^{2}$. This gives the workforce explicit rights in discourse and decision-making at the highest company level, including the appointment of executives and contract renewal. This article focuses on the effect of codetermination on productivity and bargaining power of labor.

Over the last years many articles have been written on codetermination with quite controversial results ${ }^{3}$. Besides the theoretical papers, some empirical studies have attempted to shed light on the effects of this institution (Svejnar 1982, FitzRoy and Kraft 1993, 2005, Kraft and Ugarkovic 2006, Gorton and Schmid 2004, Fauver and Fuerst 2006). Productivity, profits, stock returns, wages and employment adjustment are among the topics analyzed. However, an explicit bargaining model is not usually applied to estimate the relative

\footnotetext{
${ }^{1}$ Cf. for a survey Lawson (2011).

${ }^{2}$ Aside of Germany several other European countries have adopted employee representation at board level. These countries are Austria, Croatia, the Czech Republic (however new legislation makes this optional from 2014 onwards), Denmark, Finland, France, Hungary, Luxembourg, the Netherlands, Norway, Slovakia, Slovenia and Sweden http://www.worker-participation.eu/National-Industrial-Relations/Across-Europe/Board-levelRepresentation2

${ }^{3}$ Addison (2009) provides a very detailed survey on all aspects (theoretical and empirical) of plant and company codetermination. Among the more recent contributions, Allen, Carletti and Marquez (2014) present a theoretical model on the effects of a representation of the interests of stakeholder like employees and suppliers in the firm's decision making process. See also Baranchuk and Dybvig (2009) for a theoretical analysis of the efficiency of diverse corporate boards.
} 
bargaining power of the two parties and to identify the impact of codetermination (as well as other determinants) on the distribution of rents.

The problems stem on the one hand from the theoretical basis and on the other hand from the empirical application. The modeling of bargaining processes is complex if the theoretical model is to be suitable for empirical application. Here a theoretical model is developed to derive a very simple structural equation on the relative bargaining power of labor that is suitable for an empirical test. This test is subsequently carried out using information from 154 stock companies operating in the manufacturing industry in the years 1971 to 1990. It is therefore possible to cover time periods before and after the introduction of (quasi-) parity on the supervisory boards following the extension of Germany's codetermination law in 1976.

Codetermination takes place at the supervisory board level, with this board discussing and deciding on many strategic decisions like market development as well as on medium to longterm corporate planning like organization of production or innovation activities. These decisions have relevance on the one hand for productivity of the firms and on the other hand for division of the surplus between labor and capital (Kraft 1998, 2001). Therefore the significant extension of codetermination rights in 1976 might well affect efficiency of the organizations and bargaining power of labor.

I use an efficient bargaining model that takes account of simultaneous negotiations on wages and employment. A structural equation is derived which is subsequently used for the estimation of bargaining power in codetermined and non-codetermined firms. This structural model can also deal with pure employment bargaining.

The equation explains the wage-bill-to-sales ratio as a simple function of the labor elasticity of output and bargaining power. Hence productivity of labor is compared with its share in output. Bargaining power is identified as an add-on to the labor elasticity of output.

In the first place a production function is used to estimate the output elasticity of labor. This approach finds no productivity disadvantage of codetermined firms. Subsequently the output elasticity of labor is inserted into a non-linear equation explaining the wage-bill-to-sales ratio by variables like unionization, unemployment and codetermination to identify bargaining power. The study shows that the extension of codetermination rights has increased bargaining power of labor by about 7.4-7.9 percent. This study points to significant effects of collective bargaining laws or more general regulation of labor (Botero et al. 2004) on distribution of returns. 
There are not many studies available which actually apply a bargaining framework and confront a structural model with empirical data. Svejnar (1986) develops and estimates a bargaining model which is subsequently applied to U.S. data. Veugelers (1989) determines empirically bargaining power in Belgian industries. Bughin (1996) estimates a bargaining model by use of Belgian data to simultaneously identify product market power of firms and union bargaining power. Dobbelaere and Mairesse (2010) estimate a quite general model, which allows to identify product and labor market imperfections, as well as right-to-manage versus efficient bargaining. Hirsch and Schnabel (2014) introduce an alternative approach to identify the bargaining power of unions in Germany by considering the labor share, net wage, average unemployment duration and worker's discount rate.

Based on less explicit modelling, bargaining power is estimated by some empirical studies. Using Canadian data, Abowd and Lemieux (1993) show that wages are higher in firms with limited pressure from international competition. Van Reenen (1996) determines the extent of rent sharing due to technological innovation. Abowd and Lemieux (1993) find that 30\% of rents go to the employees and van Reenen (1996) estimates an elasticity between wages and quasi rents of 29\%. Other relevant studies in this context are Cristofides and Oswald (1991), Blanchflower, Oswald and Sanfrey (1996).

This paper is organized as follows: firstly I describe in section 2 the institutional background of the German Codetermination Act. Section 3 contains a theoretical model that is then used in an empirical application. Section 4 reports the results of our empirical study. Finally, with section 6 I draw conclusions.

\section{Institutional Details}

German stock companies and large non-traded firms with limited liability (GmbHs) are managed and controlled by a two-tier system: the management board (Vorstand) on the one hand and the supervisory board (Aufsichtsrat) on the other.

In Germany, several kinds of codetermination laws exist ${ }^{4}$. Employees are able to adopt works councils on establishment level ${ }^{5}$. On the company level three codetermination laws are

\footnotetext{
${ }^{4}$ McGaughey (2015) presents a historical view on the development of codetermination in Germany.

${ }^{5}$ Starting with FitzRoy and Kraft $(1985,1987)$, the effects of works councils have been the subject of a number of studies.
} 
relevant $^{6}$. The present study focuses on the extension of the Codetermination law which was introduced in 1951 and significantly extended in 1976 by introducing (quasi-) parity between representatives of labor and capital on the supervisory boards if companies employ 2000 employees or more ${ }^{7}$. The enlargement was legislated by the social-liberal (Social Democratic Party and Free Democratic Party) coalition governing in Germany from 1969 to 1982 led by chancellors Willy Brandt and Helmut Schmidt. Perotti and Thadden (2006) mention this intervention into corporate governance structure as the most pronounced incarnation of the attempt to let labor influence decision making.

The members of the supervisory boards are representatives of capital owners and employees. In such organizations since 1977 representatives from labor and capital have an equal number of seats on the supervisory boards. Nevertheless, in case of dispute the head of the supervisory board, appointed by the capital owners, has two votes. Therefore the term quasi-parity is used for this kind of codetermination. However, in practice disputes are rather rare.

The management boards lead companies and decide on all day-to-day business, but they have to report to the supervisory board about all important issues. Major decisions must be approved by the supervisory board. What exactly has to be fixed by the supervisory boards is usually determined by a list of approvable operations. This list can be divided into operational reporting and strategic decisions.

Operational reporting covers, among other things, information from the supervisory board about market conditions (sales, market share), employment (number of employees, costs, working time, productivity, turnover), production (production volume, inventories, material costs, capacity, innovation policy), finance (debt, equity, leverage, investment), and profitability (cash flow, profits, return on investment, liquidity). Strategic decisions with a medium to long-term relevance encompass market development (technology, general trends in the main industry, the economy and foreign markets), medium to long-term corporate planning (strategy, research and development, human resources, production, finance, forecasts

\footnotetext{
${ }^{6}$ The other two are relevant for the coal, iron and steel industry on the one hand and for companies with between 500 and 1999 employees on the other. In the former case codetermination rights are actually somewhat stronger, but only a limited number of firms are affected by this regulation. In the latter case representatives of labor occupy one third of the seats on the supervisory boards. Unfortunately it is much more difficult to identify the companies covered than in the case of quasi-parity codetermination, since no reliable list on the codetermined companies is available (and conglomerates are a frequent problem).

${ }^{7}$ The employment limit is relevant to the company alone or, if it is a conglomerate or the company has subsidiaries, the total number of employees is decisive.
} 
concerning sales volume and profits). Employment is therefore directly and indirectly affected by short- and long-term decision making.

Supervisory boards appoint the executives, and decide on contract renewals. A subcommittee of this board also determines the salaries of the top managers and the composition of remuneration in terms of fixed versus short- and long-term parts.

In contrast to most other bargaining institutions, supervisory boards may well have a larger impact, directly or indirectly, on employment than on wages ${ }^{8}$. However, wages might also be affected indirectly.

In Germany wage determination is basically a two-step process. Firstly, wage negotiations between employer associations and unions take place on industry level. Nevertheless, it has been shown that wages differ among firms, as the industry-wide agreement is frequently a substitute for a minimum wage, and wages are fixed on the firm or establishment level in a second round ${ }^{9}$. Codetermination might affect remuneration indirectly, e.g. by exerting resistance against wage concessions in cases of economically adverse situations ${ }^{10}$. Svejnar (1982) presents evidence that the introduction of codetermination has led to a wage increase in the iron and steel industry, but not in the coal mining industry.

\section{A Bargaining Model}

The utility function is based on risk neutral agents and is specified as wage differentials between remuneration in the considered firm (called $w$ ) in relation to wages earned elsewhere (outside option called $w_{a}$ ) multiplied by the number of employees $N$. The monetary value of the outside option is either unemployment benefits or a weighted average of a) employment at

\footnotetext{
${ }^{8}$ Cf. Kraft (1998, 2001).

${ }^{9}$ Note that in Germany firms are not forced to adopt collective agreements. In principle, every firm can choose between being a member of an employer association and setting wages through collective agreements or staying out of the employer association and setting wages individually.

${ }^{10}$ Gorton and Schmid (2004, 865) argue that employees might use codetermination as an insurance mechanism by resisting wage cuts and dismissals in recessions. In the case of a negative shock, employers might possibly seek to make some workers redundant. Codetermination could be used to resist to such demands, so a delay in redundancies is at least plausible. As Gorton and Schmid (2004) note, the codetermined firms would then tend to be overstaffed. This should also be reflected in the wage share if codetermined firms are compared with others. Codetermination as an insurance mechanism is also discussed by Perotti and Thadden (2006) as well as by Kim, Maug and Schneider (2015). Guertzgen (2014) presents related empirical evidence and shows that firms with works councils provide more wage insurance than other firms.
} 
a lower wage level and b) unemployment benefits where the weights are determined by the probabilities that the first or the second option applies. This monetary value is called $w_{a}$ and its value determines the lower boundary for the bargained wage $w$. Hence, the aim of labor is to maximize the function

$$
U=N\left(w-w_{a}\right)
$$

This is the well-known Stone-Geary utility function with risk-neutral workers and is frequently applied in bargaining models (examples are Blanchflower, Oswald and Sanfy 1996 and Dobbelaere 2004).

The firm simply maximizes profits by use of three production factors: labor $N$, capital $K$ and materials $M$. Workers receive the wage $w$, whilst interest rates relevant for the use of capital are denoted by $r$ and material costs are called $c$. To keep the model manageable, capital and materials are assumed to be exogenously determined and fixed in the short run. Profits are defined as the difference between sales volume $P q$ and costs for labor $w N$, capital $r K$ and materials $c M$.

$$
P q(K, N, M)-w N-r K-c M
$$

Output is determined by a simple Cobb Douglas production function: $q=N^{\alpha} K^{\beta} M^{\gamma}$ with the labor elasticity of output $\alpha$, capital elasticity of output $\beta$, output elasticity of materials $\gamma$ and firms maximize (as usual) profits. In case of dispute they have to bear the expenditures for capital and material ${ }^{11}$. I consider the realistic case of asymmetric bargaining power, and the bargaining power of the two players is denoted by $\phi$ and $1-\phi$. The aims of the two parties are combined by the well-known Nash bargaining solution:

$$
\Phi=\left(N\left(w-w_{a}\right)\right)^{\phi}\left(P N^{\alpha} K^{\beta} M^{\gamma}-w N-r K-c M-(-r K-c M)\right)^{(1-\phi)}
$$

In case of efficient bargaining the Nash product is optimized with respect to employment and wages. This leads to the following derivatives:

$$
\begin{gathered}
N=\frac{P q(\phi+\alpha-\phi \alpha)}{w} \\
w=\frac{P q \phi+n w_{a}+n \phi w_{a}}{n}
\end{gathered}
$$

\footnotetext{
${ }^{11}$ This assumption is frequently made in the literature, examples being Bughin (1996), Crepon et al. (1999), Dobbelaere (2004) Abraham et al.(2009).
} 
Solving these relations yields a simple relation for employment:

$$
N=\frac{P q \alpha}{w_{a}}
$$

Employment is determined by the labor elasticity of output and the alternative wage. Hence in this case employment is at its maximum. A similar expression for the wage leads to:

$$
w=\frac{(\phi+\alpha-\phi \alpha)}{\alpha} w_{a}
$$

These two equations can be combined to determine an expression for the wage-bill-to-sales ratio

$$
\frac{n w}{P q}=\phi+\alpha-\phi \alpha
$$

In this case the wage-bill-to-sales ratio is a simple function of the output elasticity and bargaining power. Interestingly it is independent of the alternative wage $w_{a}$. The ratio of total wage payments to sales is a popular measure for labor's bargaining power and is also applied in empirical studies (e.g. by Gorton and Schmid 2004). This procedure is supported by our simple model, where this ratio is actually determined by bargaining power (and productivity). If the simple textbook model applies and workers have no bargaining power $(\phi=0)$ the wage-bill-to-sales ratio reduces to the output elasticity of labor.

As already discussed above, the question arises whether a model based on efficient bargaining is really adequate for analyzing codetermination, as wages are rarely an explicit issue for supervisory boards ${ }^{12}$. Interestingly it is rather simple to include pure employment bargaining. Rearranging the optimality condition for employment bargaining (5), leads exactly to equation (9). Hence, with respect to equation (9), it doesn't matter whether wages and employment are determined in negotiations simultaneously or whether employment only is negotiated.

The relevance of equation (9) for efficient as well as employment bargaining is clearly advantageous, as other determinants of the outcome of bargaining are not based on employment bargaining only. Note, however pure, wage negotiations are not covered by this model.

\footnotetext{
${ }^{12}$ Cleary wages might be an implicit issue and there are specific situations possible like concession bargaining in the case of severe crisis.
} 


\section{Imperfect competition}

\section{Monopolistic Competition}

Until now prices are exogenously determined and not a function of the output produced by the firm in question. This is true for competitive markets but in many situations imperfect competition is more realistic. A simple way to consider such a situation is by including monopolistic competition ${ }^{13}$. Demand for output $q$ is determined in the following way:

$$
D=P^{\eta} Y, \eta<-1
$$

With $Y$ being a general demand factor and $\eta$ stands for the price elasticity of demand. Inverting this relation leads to an equation for price:

$$
P=D^{\varepsilon} Y^{-\varepsilon},-1<\varepsilon=\eta^{-1}<0
$$

Inventory holding is disregarded here and therefore $D=q$

Combining these relations together with the production function implies

$$
q=\left(N^{\alpha} K^{\beta} \mathrm{M}^{\gamma}\right)^{(1+\varepsilon)} Y^{-\varepsilon}
$$

The bargaining function is now

$$
\Phi=\left(N\left(w-w_{a}\right)\right)^{\phi}\left(\left(N^{\alpha} K^{\beta} M^{\gamma}\right)^{(1+\varepsilon)} Y^{-\varepsilon}-w N-r K-c M-(-r K-c M)\right)^{(1-\phi)}
$$

Optimization leads to somewhat more complicated expressions which, however, are interpreted very similarly to the relations determined earlier:

$$
\begin{gathered}
w=\frac{\phi+\alpha(1+\varepsilon-\phi-\phi \varepsilon)}{\alpha(1+\varepsilon)} w_{a} \\
N=\frac{(1+\varepsilon) P q \alpha}{w_{a}}
\end{gathered}
$$

Employment again depends on the alternative wage, output elasticity and sales. It comes as no surprise that due to $\varepsilon<0$ employment is lower than in the case of perfect competition.

The expressions for wage and employment can be used to explain the wage-bill-to-sales ratio

$$
\frac{w N}{P q}=\phi+\alpha(1+\varepsilon)-\phi \alpha(1+\varepsilon)
$$

\footnotetext{
${ }^{13}$ Many papers use a monopolistic competitive framework. Very well-known examples are Dixit and Stiglitz (1977) as well as Blanchard and Kyotaki (1987)
} 
During the estimation process to be explained below, the output elasticity of labor and the expression for demand elasticity are always simultaneously determined.

\section{Cournot Oligopoly}

As it is well known, in a Cournot model the marginal revenue function depends on output:

$$
\begin{gathered}
P q_{i}=P(Q) q_{i} \text {; with } \\
Q=\sum_{i=1}^{n} q_{i} \text { and } \\
\frac{\partial\left(P q_{i}\right)}{\partial q_{i}}=P \frac{\partial Q}{\partial q_{i}}+\frac{\partial P}{\partial Q} \frac{\partial Q}{\partial q_{i}} q_{i}
\end{gathered}
$$

The derivative of sales with respect to employment is now

$$
\frac{\partial P q_{i}}{\partial N}=P \frac{\partial Q}{\partial q_{i}} \frac{\partial q_{i}}{\partial N}+\frac{\partial P}{\partial Q} \frac{\partial Q}{\partial q_{i}} \frac{\partial q_{i}}{\partial N} q_{i}
$$

If the typical Cournot assumption $\frac{\partial Q}{\partial q_{i}}=1$ is applied the expression from above reduces to

$$
\frac{\partial\left(P q_{i}\right)}{\partial N}=\left(P+\frac{\partial P}{\partial q_{i}} q_{i}\right) \frac{\partial q_{i}}{\partial N}
$$

Straightforward rearrangements lead to

$$
\frac{\partial\left(P q_{i}\right)}{\partial N}=P\left(1+\frac{s_{i}}{\eta}\right) \frac{\partial q_{i}}{\partial N}
$$

The term $s_{i}$ stands for the individual market share and $\eta$ represents the demand elasticity. Taking into account the Cobb-Douglas production function from above leads to the following relation

$$
\frac{\partial\left(P q_{i}\right)}{\partial N}=P\left(1+\frac{s_{i}}{\eta}\right) \alpha \frac{q_{i}}{N}
$$

Just to simplify notation, I introduce $a=\left(1+\frac{s_{i}}{\eta}\right)$. When the logarithmic Cobb-Douglas production function is estimated, not $\alpha$ is identified but 


$$
\frac{\partial \ln \left(P q_{i}\right)}{\partial \ln N}=a \alpha
$$

If this is taken up in the bargaining model the following relation for the wage-bill-to-sales ratio emerges:

$$
\frac{w N}{P q}=\phi+a \alpha-\phi a \alpha
$$

The upshot of the consideration of these two simple models of imperfect competition is that in principle the bargaining model is not affected. The estimated production elasticities are determined somewhat differently, but this has no effect on the analysis of the distribution process.

\section{Empirical analysis}

\subsection{Data}

The empirical model is based on a difference-in-differences approach. The extended codetermination law became effective in 1976 but the firms were granted a transition period until 1978 to install supervisory boards with a new allocation of the seats. The empirical test is based on data from stock companies from 1971 to 1990. The advantage of this particular data source is the coverage of periods before and after the major extension of the codetermination laws in 1976.

This test is based on an unbalanced panel of 154 firms from the manufacturing sector which are observed for six periods before (1971 to 1976) and 11 years (1980 to 1990) after the introduction of the extended codetermination law ${ }^{14}$. The years 1977 to 1979 are omitted because of the mentioned transition periods for installing the newly introduced supervisory boards. Furthermore, adjustment problems might contaminate the "true" effects of codetermination. This leads to a total of 2145 observations if a fixed effects model is applied and to 1803 observations in the case of system $\mathrm{GMM}^{15}$.

\footnotetext{
14 The origin of the data is the German Finance Data Base (Deutsche Finanzdatenbank/ Jahresabschlussdatenbank), which was extended Hoppenstedt's Handbook of German Corporations (Handbuch der Deutschen Aktiengesellschaften) as well as from the annual statements of accounts.

${ }^{15}$ In Germany the number of stock companies is generally smaller than for example in the U.S. Furthermore, only companies from the manufacturing sector are considered, whilst firms from the steel and iron producing industry are excluded, since they are subject to the specific and somewhat stronger codetermination law in the coal, iron and steel industry
} 


\subsection{Estimation of a Production Function}

The empirical test is implemented in two steps. In the first place a simple Cobb-Douglas production function is estimated. The estimation is based on the use of capital, labor and material costs as explanatory variables. The dependent variable is sales volume. Sales, capital and materials are divided by the relevant industry-specific producer price index. The coefficients of the production factors stand for the output elasticities if perfect competition applies, or additionally reflect effects of product differentiation by including $1+\varepsilon$ or oligopoly markups by the additional factor $a=\left(1+\frac{s_{i}}{\eta}\right)$.

\section{Fixed effects model}

The estimation of the production function is based on a fixed effect panel model. Time dummies are also included. In principle it would be desirable to identify separate estimates of $\alpha$ for every single firm. However in practice the limited number of observations per firm does not allow a consistent identification of the individual production elasticities (in particular in a fixed effects model). However, some differentiation and disaggregation is still possible: Labor is differentiated according to employment in non-codetermined firms, employment in codetermination firms in periods before the enlargement became effective (1971 respectively 1973 in case of GMM until 1976) and employment in codetermined firms after the enlargement became effective from 1980 onwards. Three different (broadly defined) industries are also distinguished to take account of specific technological conditions. The industries are: production of consumer goods, production of industrial goods and investment and production of durable goods. Clearly, the intention is to take account of possible productivity differences which should be reflected in the share of output that goes to labor.

The results are shown in table 1 . Note that these results are based on the estimation of one regression in which differences between codetermined and non-codetermined firms and among industries are modeled by interactions. As an additional covariate the six firm concentration index is included. The intention is to take account of price effects of imperfect competition, which could be reflected in higher revenues. 
The coefficients have reasonable magnitudes, but for two industries (investment goods and industrial and durable goods) the performed Wald tests reject the hypothesis of constant returns to scale, which is not an unusual result in fixed effects models ${ }^{16}$.

Comparing the codetermined firms before and after the enlargement of the law, this enlargement leads to somewhat higher output elasticities of labor. In the case of investment and durable goods industry the differences are significant. This shows that codetermination does not reduce efficiency as sometimes supposed.

Table 1: Fixed-Effects Regression with log of Sales as Dependent Variable

$\begin{array}{llc}\text { Independent variables } \quad \text { Consumer goods } & \text { Industrial goods } & \begin{array}{c}\text { Investment and } \\ \text { durable goods }\end{array}\end{array}$

\begin{tabular}{|c|c|c|c|}
\hline $\begin{array}{l}\text { Ln (Labor) (codetermination. = } \\
\text { 0) }\end{array}$ & $\begin{array}{l}0.256^{* * *} \\
(0.035)\end{array}$ & $\begin{array}{l}0.204 * * * \\
(0.031)\end{array}$ & $\begin{array}{l}0.223 * * * \\
(0.027)\end{array}$ \\
\hline $\begin{array}{l}\text { Ln (Labor) (codetermination } \\
\text { before 1976) }\end{array}$ & $\begin{array}{c}0.248 * * * \\
(0.035)\end{array}$ & $\begin{array}{l}0.210 * * * \\
(0.031)\end{array}$ & $\begin{array}{c}0.228 * * * \\
(0.026)\end{array}$ \\
\hline $\begin{array}{l}\text { Ln (Labor) (codetermination } \\
\text { after 1976) }\end{array}$ & $\begin{array}{l}0.251^{* * *} \\
(0.036)\end{array}$ & $\begin{array}{l}0.213 * * * \\
(0.032)\end{array}$ & $\begin{array}{l}0.232 * * * \\
(0.026)\end{array}$ \\
\hline Ln (Material costs) & $\begin{array}{l}0.650 * * * \\
(0.029)\end{array}$ & $\begin{array}{l}0.61 * * * \\
(0.039)\end{array}$ & $\begin{array}{l}0.652 * * * \\
(0.019)\end{array}$ \\
\hline Ln (Capital) & $\begin{array}{c}0.089 * * * \\
(0.023)\end{array}$ & $\begin{array}{c}0.099 * * * \\
(0.035)\end{array}$ & $\begin{array}{c}0.070 * * * \\
(0.020)\end{array}$ \\
\hline Concentration & $\begin{array}{l}0.003 * * \\
(0.001)\end{array}$ & $\begin{array}{l}0.003^{* *} \\
(0.001)\end{array}$ & $\begin{array}{l}0.003 * * \\
(0.011)\end{array}$ \\
\hline No of obs. & & 2145 & \\
\hline $\mathrm{R}^{2}$ & & 0.98 & \\
\hline
\end{tabular}

\footnotetext{
${ }^{16}$ As a robustness check I also experimented with lagged values of the production factors. This did not change the insights.
} 


\section{Dynamic system-GMM panel model}

The fixed effects model addresses time-invariant unobserved heterogeneity like management quality, which may bias the results if this unobserved heterogeneity is correlated with other variables. However, there might also feed-back effects be present like demand shocks which affect output and input factor simultaneously. To cope with time-invariant fixed effects and possible endogeneity problems in addition a system-GMM model is used. The system GMM estimator combines time differencing of the variables with instrumenting endogenous variables by lagged levels and differences of these covariates. Necessary conditions for validity of this approach are absence of second order autocorrelation in the differenced errors (Arellano-Bond test) and the validity of the overidentification moment conditions in the presence of robust standard errors (Hansen $\mathrm{J}$ test). The model is dynamic and includes the lagged dependent variable. The two-step estimator is used, the standard errors are clustered and the Windmejjer (2005) finite sample correction of the standard errors is applied.

Endogenous variables are the production factors labor, capital and material. Predetermined is concentration. Because of the weak instrument problem not all possible lags are used, but just the lags from $t-2$ and $t-3$. Table 2 presents the result of the system GMM estimations. 
Table 2: Dynamic System GMM with log of Sales as Dependent Variable

$\begin{array}{llc}\text { Independent variables } \quad \text { Consumer goods } \quad \text { Industrial goods } & \begin{array}{c}\text { Investment and } \\ \text { durable goods }\end{array}\end{array}$

\begin{tabular}{lccc}
\hline \hline InSales(t-1) & $\begin{array}{c}.211^{* * *} \\
(0.037)\end{array}$ & $\begin{array}{c}.211^{* * *} \\
(0.037)\end{array}$ & $\begin{array}{c}0.211^{* * *} \\
(0.037)\end{array}$ \\
\hline \hline Ln (Labor) (codetermination. $=$ & $0.138^{* * *}$ & $0.150^{* * *}$ & $0.183^{* * *}$ \\
0) & $(0.027)$ & $(0.030)$ & $(0.027)$ \\
Ln (Labor) (codetermination & $0.140^{* * *}$ & & \\
& $(0.025)$ & $0.145^{* * *}$ & $0.179 * * *$ \\
before 1976) & & $(0.028)$ & $(0.026)$ \\
& $0.143^{* * *}$ & & \\
Ln (Labor) (codetermination & $(0.025)$ & $0.148^{* * *}$ & $0.180^{* * *}$ \\
=after 1976) & & $(0.029)$ & $(0.026)$ \\
& $0.540^{* * *}$ & $0.48^{* * *}$ & $0.502^{* * *}$ \\
Ln (Material costs) & $(0.039)$ & $(0.038)$ & $(0.038)$ \\
& $0.085^{* * *}$ & $0.146^{* * *}$ & $0.104^{* *}$ \\
Ln (Capital) & $(0.028)$ & $(0.036)$ & $(0.027)$ \\
& 0.0004 & 0.004 & 0.004 \\
Concentration & $(0.001)$ & $(0.001)$ & $(0.001)$ \\
\hline \hline
\end{tabular}

No of obs.

1803

Number of instruments 354

Arellano-Bond test on AR(2) in first differences $\mathrm{p}=.817$

Hansen $\mathrm{J}$ Test on overidentifying restrictions $\mathrm{p}=.846$

Notes: $* * *$ indicates statistical significance at the $1 \%$ level. All results are two-step system GMM estimates. Time dummies are included but not reported. Parentheses contain clustered standard errors which are based on the finite sample correction proposed by Windmeijer (2005). Clustering takes place at firm level.

Returns to scale are tested by Wald tests on a restricted model with $\ln \operatorname{Sales}(t-1)=0$. Results are presented in table (3) below. Constant returns are now only rejected in one case: codetermined firms before the enlargement of the law active in the industrial goods industry. No significant differences between the coefficients of the output elasticities of labor are estimated. 
Table 3: Restricted System GMM with log of Sales as Dependent Variable without lagged dependent variable

\begin{tabular}{|c|c|c|c|}
\hline Independent variables & Consumer goods & Industrial goods & $\begin{array}{l}\text { Investment and } \\
\text { durable goods }\end{array}$ \\
\hline $\begin{array}{l}\text { Ln (Labor) (codetermination. = } \\
\text { 0) }\end{array}$ & $\begin{array}{l}0.193 * * * \\
(0.05)\end{array}$ & $\begin{array}{l}0.185 * * * \\
(0.041)\end{array}$ & $\begin{array}{l}0.247 * * * \\
(0.031)\end{array}$ \\
\hline $\begin{array}{l}\text { Ln (Labor) (codetermination } \\
\text { before 1976) }\end{array}$ & $\begin{array}{c}0.194^{* * *} \\
(0.043)\end{array}$ & $\begin{array}{c}0.179 * * * \\
(0.034)\end{array}$ & $\begin{array}{c}0.240 * * * \\
(0.032)\end{array}$ \\
\hline $\begin{array}{l}\text { Ln (Labor) (codetermination } \\
\text { =after 1976) }\end{array}$ & $\begin{array}{l}0.195 * * * \\
(0.052)\end{array}$ & $\begin{array}{l}0.183^{* * * *} \\
(0.034)\end{array}$ & $\begin{array}{l}0.240 * * * \\
(0.033)\end{array}$ \\
\hline Ln (Material costs) & $\begin{array}{l}0.644^{* * * *} \\
(0.057)\end{array}$ & $\begin{array}{l}0.589 * * * \\
(0.0334)\end{array}$ & $\begin{array}{l}0.617 * * * \\
(0.043)\end{array}$ \\
\hline Ln (Capital) & $\begin{array}{c}0.129 * * * \\
(0.047)\end{array}$ & $\begin{array}{c}0.202 * * * \\
(0.040)\end{array}$ & $\begin{array}{c}0.133 * * \\
(0.041)\end{array}$ \\
\hline Concentration & $\begin{array}{r}0.0006 \\
(0.001) \\
\end{array}$ & $\begin{array}{r}0.006 \\
(0.001) \\
\end{array}$ & $\begin{array}{r}0.006 \\
(0.001) \\
\end{array}$ \\
\hline \multicolumn{4}{|c|}{$\begin{array}{l}\text { No of obs. } \\
\text { Number of instruments } 328 \\
\text { Arellano-Bond test on } \operatorname{AR}(2) \text { in first differences } p=.189 \\
\text { Hansen J Test on overidentifying restrictions } p=.769\end{array}$} \\
\hline \multicolumn{4}{|c|}{$\begin{array}{l}\text { Notes: }{ }^{* * *} \text { indicates statistical significance at the } 1 \% \text { level. All results are two-step system GMM estimates. } \\
\text { Time dummies are included but not reported. Parentheses contain clustered standard errors which are based on } \\
\text { the finite sample correction proposed by Windmeijer (2005). Clustering takes place at firm level. }\end{array}$} \\
\hline
\end{tabular}




\subsection{Determinants of Bargaining Power}

Equations (9) and (16) are non-linear relations between bargaining power, output elasticity of labor, inverse of price elasticity, bargaining power $\phi$ and the wage bill to sales ratio. Bargaining power in turn is empirically identified by some economic variables. In particular the following relation is used

$$
\phi=\gamma_{0}+\gamma_{1} C O D A L+\gamma_{2} C O D E F F+\beta_{i} Z_{i}+\tau_{t} T_{t}
$$

In the next step the coefficients of the variables lnemployment (the different values of $\alpha$ respectively $\alpha(1+\varepsilon))$ are used in a non-linear least square estimation. The main interest is clearly the determination of possible bargaining effects exerted by the extension of codetermination rights. As usual in difference-in-differences models of this kind the most important variable enters the equation twice: the variable $C O D A L$ has unit value for codetermined firms for all years, whereas CODEFF has unit value if codetermination is effectively at work. This means the firms are codetermined and the time periods considered are the years from 1980 onwards. Hence the marginal effect of $\operatorname{CODEFF}\left(\gamma_{2}\right)$ is the interesting parameter. $Z_{i}$ stands for a number of covariates to be explained below and the $T_{t}$ variables represent time dummies.

Puhani (2012) discusses the identification and estimation of treatment effects in non-linear difference-in-differences models and suggests using the difference in the expected value if the relevant variable assumes the values zero and one (similarly to the estimation of marginal effects in the case of dummy variables). I follow this suggestion.

Time dummies are also included within the bargaining equation. Furthermore 17 two-digit industry dummy-variables $I_{j}$ are added, but outside of the bargaining equation ${ }^{17}$. The industry-dummies identify the coefficients $\delta_{j}$. The equation to be estimated now looks like this:

$$
\begin{aligned}
& \ln \left(\frac{w N}{P q}\right)_{i}=\left(\gamma_{0}+\gamma_{1} \operatorname{CODAL}_{i}+\gamma_{2} \mathrm{CODEFF}_{i}+\beta_{i} Z_{i}+\tau_{t} T_{t}\right)+\alpha \\
& -\left(\gamma_{0}+\gamma_{1} \mathrm{CODAL}_{i}+\gamma_{2} \mathrm{CODEFF}_{i}+\beta_{i} Z_{i}+\tau_{t} T_{t}\right) \alpha+\delta_{j} I_{j}
\end{aligned}
$$

\footnotetext{
17 Including them in the bargaining equation implies a somewhat different assumption concerning the determination of bargaining power, but this does not alter the results.
} 
This equation is estimated by non-linear least squares. The dependent variable is specified as a logarithmic value. In the case of a logarithmic dependent variable the interpretation of the coefficients is quite straightforward as a relative impact. Hence the marginal effect of CODEFF tells us to what extent bargaining power has increased (or decreased or has not been affected by the extension of the codetermination law). The effect of codetermination will be exactly measured as $e^{\omega}-1$ with $\omega$ being the estimated value of the treatment effect. In the given context a specification which identifies the relative impact $o$ codetermination on bargaining power appears to be quite useful.

The use of accounting firm data offers only limited access to useful covariates of potential interest. However, some interesting information can be obtained from other sources. Clearly working time is not constant over time and between firms, and hours in turn will affect the wage bill. Data on overtime hours per employee is published at industry level and this is used to represent the general state of demand in an industry.

The skill levels of employees will in all likelihood affect wages directly due to productivity effects (remember firm-specific coefficients cannot be estimated) and may possibly also affect bargaining power. As a proxy variable I use the innovation intensity of a firm by computing the number of patents per employee (Patents per employee). Innovative firms usually employ better skilled workers and pay higher wages.

It is sometimes argued that firms in concentrated industries employ better qualified workers and this in turn will affect the wage bill ${ }^{18}$. Another argument points into the opposite direction: Monopoly power reduces the labor share in output as prices rise due to a higher mark-up on costs, but wages do not (if concentration is not associated with higher unionism $)^{19}$. This argument is also valid in this context if my output elasticities of labor are not disaggregated enough to take account of different market structures. Given that I only consider three broadly defined industries this might well be the case. Hence concentration might assume positive or negative values. The degree of imperfect competition is measured on the two-digit industry level as the six firm concentration ratio.

Standard variables in bargaining models are unemployment and union density. Unemployment is available on the level of the German Bundesländer (10 Bundesländer

\footnotetext{
${ }^{18}$ Cf. Belman and Heywood (1990), who consider the interaction between concentration, innovation and qualification.

${ }^{19}$ Cf. e.g. Conyon (1994).
} 
before the reunification) and included as a further control variable. Unionization can be computed in the following way: in Germany several industry unions exist. Computation of unionization is done in the following way: information is available on the number of union members, the industries for which they are responsible (this is usually more than just a single industry), and the number of employees in the relevant industries. On the basis of this information the share of unionized employees is computed. This is the gross rate of unionization and an upper estimate of unionization because some members of the unions are unemployed or retired.

Union density is frequently regarded as a factor correlated with bargaining power and in the given context this is relevant in two ways. Firstly, bargaining power will most likely have an impact on the base level of wages, which (as explained earlier) is determined by negotiations taking place at industry level. Secondly, high unionization probably reflects the attitude of the workforce in general towards the representation of workers' rights in bargaining processes. This in turn may be a good indicator of what workers expect from their representatives on the supervisory boards. These are frequently members of the works councils, who are elected every four years by the employees.

Following Koenker and Hallock (2001) I adjust the continuous variables by subtracting from the observed value its respective mean value. This approach has the advantage that the constant term, in this case called centercept, can be interpreted as the mean bargaining power of non-codetermined firms with average values for overtime hours, innovation intensity concentration, union density and unemployment. It does not, in contrast to the classical intercept, express an out-of-sample prediction.

The empirical model is basically a two stage procedure where production elasticities of labor are estimated in the first place. These estimates are used in the second step. In two stage approaches of this kind the conventional standard errors are not valid. Therefore I use bootstrapping with cluster adjustment and 200 replications. Note, this bootstrapping is based on the inclusion of both parts of the estimation procedure for every bootstrap sample.

The second stage nonlinear least square-estimations of the bargaining function are carried out two times using the respective output elasticity estimates of the production functions from the fixed effects and the system GMM regressions. The results based on output elasticities of labor from the fixed effects estimation are presented in table three. All specifications include time and 17 two-digit industry dummies. Column (1) is the preferred specification. Note, 


\section{Table 4: NLS Regression Results based on the fixed effects model}

(1)

$\operatorname{Ln}($ Share of labor costs)
(2)

Ln(Share of $\operatorname{Ln}($ Share of

labor costs) labor costs)

Constant

$$
\begin{array}{ccc}
-1.653 * * * & -1.524 * * * & -1.415 * * * \\
(0.091) & (0.078) & (0.075)
\end{array}
$$

CODAL

$$
\begin{gathered}
0.020 \\
(0.028)
\end{gathered}
$$

0.022

$-0.027$

(0.028)

$(0.028)$

[treatment. eff.]

$$
\begin{array}{ccc}
{\left[\begin{array}{c}
0.016 \\
(0.022)
\end{array}\right]} & {\left[\begin{array}{c}
-0.017 \\
(0.022)
\end{array}\right]} & {\left[\begin{array}{c}
-0.021 \\
(0.022)
\end{array}\right]} \\
0.094 * * * & 0.092 * * * & 0.095 * * * \\
(0.032) & (0.032) & (0.033)
\end{array}
$$

CODEFF

[treatment. eff.]

$$
\left[\begin{array}{c}
0.072 * * * \\
(0.025)
\end{array}\right]
$$

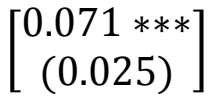

$\left[\begin{array}{c}0.073^{* * *} \\ (0.025)\end{array}\right]$

$$
.062 * * *
$$

Overtime hours

(0.019)

(0.019)

(0.019)

Patents per

$$
\begin{gathered}
0.071^{* * * *} \\
(0.014)
\end{gathered}
$$

$0.072 * * *$

$0.070 * * *$

employee*100

(0.014)

Concentration

$$
0.019 * * *
$$

$0.019 * * *$

$0.019 * * *$

(0.002)

(0.002)

(0.002)

Unemployment

$$
\text { (0.004) }
$$

Ln(Unemployment)

$$
-0.127 * * *
$$

Unionization

$$
0.556 * * *
$$$$
0.565 * * *
$$

(0.151)

$(0.151)$

(0.151)

Time dummies Industry dummies

$$
\begin{aligned}
& \text { Yes } \\
& \text { Yes }
\end{aligned}
$$

Yes

Yes

Yes

Yes

No. of obs.

2145

Notes: *** indicates statistical significance at the $1 \%$ level. Parentheses contain bootstrapped and clustered standard errors. Clustering takes place at firm level. Squared brackets contain the average marginal effects. Standard errors of the marginal effects are calculated by the delta method, they are bootstrapped and clustered.

unemployment enters the equation here as a logarithmic value. Column (3) presents the results with the non-logarithmized variable unemployment. 
It might be argued that, if wages are high in general, a feedback effect from the wage bill to unemployment causes an endogeneity problem. IV methods are rather difficult in such nonliner relations and a convincing instrument is not available. Therefore in one specification (presented in column 2) this variable is simply excluded. This omission does not alter the main results ${ }^{20}$.

The results point to a significant effect of the extension of the codetermination rights on the wage-bill-to-sales ratio. As the productivity effect is included by the output elasticity, the results point to a redistribution effect beyond productivity. Hence, according to the outcome of the applied model, the extension of the codetermination law has had an impact on bargaining power.

Next, the NLS-estimations are repeated by use of the output elasticities of labor computed by system GMM. The results are presented in table 4. The result concerning the enlargement of codetermination are just a little bit above those reported in table 3 and are surprisingly close to those shown in table three. Applying the transformation $e^{\omega}-1$ to all presented marginal effects in the two tables, the increase in bargaining power is within a range of 7.4-7.9\%. The constant term stands for the average bargaining power (in the base industry) in firms without codetermination. However, the codetermination law had no impact on bargaining power before its extension and therefore the estimate $e^{\gamma_{0}}\left(\gamma_{0}\right.$ is the constant term) stands for the bargaining power in both firm types. This points to an average bargaining power of about 0.22-0.27, which does not look unrealistic.

The included control variables display the expected signs and are significant. Average overtime at industry level raises the wage-bill-to-sales ratio. Similarly innovative firms have a higher wage-bill-to-sales ratio, which is presumably explained by the employment of better skilled and better paid employees. Employees of firms active in highly concentrated industries receive a larger share of sales. Unemployment reduces the labor share, while union density increases it. Hence the control variables work in the expected way.

\footnotetext{
20 The variables overtime hours, concentration and patent might determine the rent to a larger extent than bargaining power. As the dependent variable is a ratio with sales volume in the denominator, this is probably of limited relevance. Nevertheless, an equation with no covariates except unionization is estimated. The marginal effect of codetermination loses some of its significance, but the effect is close to the one reported in the other columns.
} 
Table 5: NLS Regression Results based on the system GMM model (column 1-3 dynamic GMM, column 4 restricted system GMM)
(1)
(2)
(3)
(4)

Dep. Var

Ln(Share of

Ln(Share of

Ln(Share of

Ln(Share of labor costs)

labor costs)

labor costs)

labor costs)

Constant

$$
\begin{gathered}
-1.509 * * * \\
(0.078)
\end{gathered}
$$

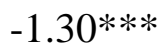

$-1.509 * * *$

CODAL

$$
0.031
$$

(0.062)

(0.072)

[treatment eff.]

$$
(0.030)
$$

$$
\begin{gathered}
0.030 \\
(0.030)
\end{gathered}
$$

\begin{tabular}{|c|c|c|c|c|}
\hline & {$\left[\begin{array}{c}0.024 \\
(0.032)\end{array}\right]$} & {$\left[\begin{array}{c}-0.024 \\
(0.023)\end{array}\right]$} & {$\left[\begin{array}{c}-0.028 \\
(0.024)\end{array}\right]$} & {$\left[\begin{array}{c}0.023 \\
(0.021)\end{array}\right]$} \\
\hline CODEFF & $\begin{array}{c}0.095 * * * \\
(0.034)\end{array}$ & $\begin{array}{c}0.095^{* * * *} \\
(0.034)\end{array}$ & $\begin{array}{c}0.097 * * * \\
(0.034)\end{array}$ & $\begin{array}{c}0.096 * * * \\
(0.031)\end{array}$ \\
\hline [treatment eff.] & {$\left[\begin{array}{c}0.074 * * * \\
(0.025)\end{array}\right]$} & {$\left[\begin{array}{c}0.074 * * * \\
(0.026)\end{array}\right]$} & {$\left[\begin{array}{c}0.076^{* * *} \\
(0.027)\end{array}\right]$} & {$\left[\begin{array}{l}0.075^{* * *} \\
(0.024)\end{array}\right]$} \\
\hline Overtime hours & $\begin{array}{c}.007 * * * \\
(.020)\end{array}$ & $\begin{array}{c}0.004^{* * * *} \\
(0.020)\end{array}$ & $\begin{array}{c}0.0004^{* * * *} \\
(0.0020)\end{array}$ & $\begin{array}{l}-0.030^{*} \\
(0.018)\end{array}$ \\
\hline $\begin{array}{l}\text { Patents per } \\
\text { employee*100 }\end{array}$ & $\begin{array}{c}0.091 * * * \\
(0.017)\end{array}$ & $\begin{array}{c}0.091^{* * *} \\
(0.017)\end{array}$ & $\begin{array}{c}0.090 * * * \\
(0.017)\end{array}$ & $\begin{array}{c}0.083 * * * \\
(0.013)\end{array}$ \\
\hline Concentration & $\begin{array}{c}0.016 * * * \\
(0.003)\end{array}$ & $\begin{array}{c}0.016^{* * *} \\
(0.003)\end{array}$ & $\begin{array}{c}0.017 * * * \\
(0.003)\end{array}$ & $\begin{array}{c}0.014^{* * * *} \\
(0.002)\end{array}$ \\
\hline Unemployment & & $\begin{array}{c}-0.019 * * * \\
(0.004)\end{array}$ & & \\
\hline Ln(Unemployment) & $\begin{array}{c}-0.122 * * * \\
(0.029)\end{array}$ & & & $\begin{array}{c}-0.120 * * * \\
(0.026)\end{array}$ \\
\hline Unionization & $\begin{array}{c}0.300 * * * \\
(0.150)\end{array}$ & $\begin{array}{c}0.305^{* * *} \\
(0.148)\end{array}$ & $\begin{array}{c}0.286^{* * *} \\
(0.149)\end{array}$ & $\begin{array}{c}0.210 \\
(0.141)\end{array}$ \\
\hline Time dummies & Yes & Yes & Yes & Yes \\
\hline Industry dummies & Yes & Yes & Yes & Yes \\
\hline No. of obs. & 1803 & & & \\
\hline
\end{tabular}

0.036

0.029

(0.030)

(0.027)

Notes: *** indicates statistical significance at the $1 \%$ level. Parentheses contain bootstrapped and clustered standard errors. Clustering takes place at firm level. Squared brackets contain the average marginal effects. Standard errors of the marginal effects are calculated by the delta method, they are bootstrapped and clustered. 
This result is consistent with the estimations of Gorton and Schmid (2004), who explain logarithmic value of the ratio of employees to sales and the log ratio of the wage bill to sales by codetermination (and covariates). However, one difference to their study is the consideration of productivity effects. The empirical results of this study are also in accordance with the study of Petry (2015), who shows that the enlargement of codetermination led to a decline in shareholder wealth. Related evidence on the effect of labor unions as shareholders in the U.S. is presented by Agrawal (2012) and by Ahern and Dittmar (2012) on the impact of the imposition of a $40 \%$ quota of female members of the boards of directors of publicly listed firms in Norway. However, Ginglinger, Megginson and Waxin (2011) find no significant impact of the presence of directors elected by employees on firm value or profitability.

\section{Conclusion}

I use a simple bargaining model to derive a relation between the wage-bill-to-sales ratio and bargaining power as well as the output elasticity of labor. Bargaining power is identified by comparing the labor elasticity of output with the share of sales that goes to labor. The estimation of a production function by a within and a dynamic system GMM model produce rather similar results and do not point to productivity disadvantages of codetermined firms. The labor elasticity of output is subsequently inserted into the bargaining equation to identify determinants of bargaining power. Some standard control variables to determine bargaining power of labor like unemployment and unionization are included in addition.

The bargaining equation is separately estimated on the basis of the within and the system GMM output elasticities. The results are in both cases pretty close. I find evidence for an increase in bargaining power by about 7.4-7.9 \% related to the extension of the Codetermination Act in 1976. Summarizing, the extension of the codetermination law did not harm efficiency, as sometimes supposed, but it increases bargaining power of labor and affects the distribution of rents.

Clearly the model is based on restrictive assumptions. On the other hand, it leads to a quite simple equation which can be empirically tested. Most likely the relation used to identify bargaining power is of relevance above the question of codetermination.

In future work I intend to apply more general specifications. One extension might be a less restrictive production function. Another idea is to employ a utility function, which allows for risk aversion on the part of the employees. Moreover at the moment I ignore the second main 
pillar of German industrial relations, the works councils. Works councils are active on the plant level, and it is quite likely that works council affect efficiency of production and bargaining power of labor. In contrast to codetermination on the company level, mediumsized firms with less than 2000 employees frequently have works councils ${ }^{21}$ and it would be useful to compare their effects with that of codetermination.

\footnotetext{
${ }^{21}$ Works councils are not mandatory but the workforce must be allowed the option of establishing one.
} 


\section{References}

Abraham, F., Konings, J. and Vanormelingen, S. (2009), The Effects of Globalization on Union Bargaining and Price-Cost Margins, Review of World Economics, vol. 145, 13-36.

Addison, J.T. (2009), The Economics of Codetermination, Lessons from the German Experience, Palgrave Macmillan: New York, NY USA and Basingstoke, Hampshire UK.

Agrawal, Ashwini K. (2012), Corporate Governance Objectives of Labor Union Shareholders: Evidence from Proxy Voting, Review of Financial Studies 25, 187-226.

Ahern, K., R. and Ditmar, A.K. (2012), The Changing of the Boards: The Impact on Firm Valuation of Mandated Board Representation, Quarterly Journal of Economics, vol. 127, 137197.

Allen, F., Varletti, F. and Marquez, R. (2014), Stakeholder Governance, Competition, and Firm Value, forthcoming Review of Finance.

Baranchuk, N. and Dybvig, P.H. (2009), Consensus in Diverse Corporate Boards, Review of Financial Studies, vol. 64, 341-374.

Belman, D. and Heywood, J. (1990), Market Structure and Worker Quality, Journal of Industrial Economics, vol. 39, 155-168.

Blanchard, O.J. and Kiyotaki, N. (1987), Monopolistic Competition and the Effects of Aggregate Demand, American Economic Review, vol. 77, 647-666.

Blanchflower, D.G., Oswald, A.J. and Sanfey, P. (1996), Wages, Profits, and Rent-Sharing, Quarterly Journal of Economics, vol. 227- 251.

Botero, Juan C., Simeon Djankov, Rafael La Porta, Florencio Lopez-de-Silanes, and Andrei Shleifer (2004), The regulation of labor, Quarterly Journal of Economics 119, 1339-1382.

Boulhol, H., Dobbelaere, S. and Maioli, S. (2001) Imports as Product and Labor Market Discipline, British Journal of Industrial Relations, vol. 49, 331-361.

Bughin, J. (1996) Trade Unions and Firms’ Product Market Power, Journal of Industrial Economics, vol. 44, 289-307.

Conyon, M.J. (1994), Labour's share, market structure and trade unionism, International Journal of Industrial Organization, vol. 12, 117-131.

Crepon,B., Desplatz,R. and Mairesse,J. (1999), Estimating Price Cost Margins, Scale Economies and Workers' Bargaining Power at the Firm Level, Institut National de la Statistique et des Études Économiques, G 9917.

Dixit, A. and Stiglitz, J.E. (1977), Monopolistic Competition and Optimum Product Diversity, American Economic Review, vol. 67, 297-308.

Dobbelaere, S. (2004), Estimation of Price-Cost Margins and Union Bargaining Power for Belgian Manufacturing, International Journal of Industrial Organization, vol. 22, 1381-1398.

Dobbelaere, S. and Mairesse, J. (2010), Panel Data Estimates of the Production Function and Product and Labor Market Imperfections, IZA, Discussion Paper No. 5176.

Fauver, L. and Fuerst, M.E. (2006), Does good corporate governance include employee representation? Evidence form German corporate boards, Journal of Financial Economics, vol. 82, 673-710. 
FitzRoy, F.R. and Kraft, K. (1985), Unionization, Wages, and Efficiency: Theories and Evidence from the U.S. and West Germany, Kyklos, vol. 38, 537-554.

FitzRoy, F.R. and Kraft, K. (1987), Efficiency and Internal Organization: Works Councils in West German Firms, Economica, vol. 54, 493-504.

FitzRoy, F.R. and Kraft, K. (1993), "Economic Effects of Codetermination", Scandinavian Journal of Economics, vol. 95, 365-375.

FitzRoy, F.R. and Kraft, K. (2005), “Co-Determination, Efficiency, and Productivity“, British Journal of Industrial Relations, vol. 43, 233-247.

Ginglinger, E., Megginson, W. and Waxin, T. (2011), Employee Ownership, Board Representation, and Corporate Financial Policies, Journal of Corporate Finance, vol. 17, 868887.

Guertzgen, N. (2014), Wage Insurance within German Firms: Do Institutions Matter? Journal of the Royal Statistical Society: Series A, vol. 177, 345-369.

Gorton, G. and Schmid, F.A. (2004), Capital, Labor and the Firm: A Study of German Codetermination, Journal of the European Economic Association, vol. 2, 863-905.

Hirsch, B. and Schnabel, C. (2014) What Can We Learn from Bargaining Models about Union Power? The Decline in Union Power in Germany 1992-2009, Manchester School, 347362.

Kim, E.H., Maug, E. and Schneider, C. (2015), Labor Representaion in Governance as an Insurance Mechanism, ECGI Working Paper Sereis in Finance, No. 411/2014.

Koenker, R. and Hallock, K. F. (2001), "Quantile Regression“, Journal of Economic Perspectives, vol. 15, 143-156.

Kraft, K. and Ugarkovic, M. K. (2006), "Gesetzliche Mitbestimmung und Kapitalrendite“ (2006), Jahrbücher für Nationalökonomie und Statistik, vol. 226, 588-604.

McGaughey, E. (2015), The Codetermination Bargains: The History of German Corporate and Labour Law, LSE Law, Society and Economy Working Papers 10/2015.

Lawson, N.P. (2011), Is Collective Bargaining Pareto Efficient? A Survey of the Literature, Journal of Labor Research, vol. 32, 282-304.

Perotti, E. C. and v. Thadden, E.-L. (2006), The Political Economy of Corporate Control and Labor Rents, Journal of Political Economy, vol. 114, 145-175.

Petry, Stefan (2015), Workers on the Board and Shareholder Wealth: Evidence from a Natural Experiment, Working Paper, University of Melbourne.

Puhani, P. (2012), The Treatment Effect, the Cross Difference, and the Interaction Term in nonlinear “Difference-in-Differences” Models, Economics Letters, vol. 115, 85-87.

Sanfy, P.J. (1998), Bargaining, Efficiency Wages, and the Price-Cost Markup, Economics Letters, vol. 58, 193-197.

Svejnar, J. (1982), Employee Participation in Management Decisions, Bargaining Power and Wages, European Economic Review, vol. 18, 291.303.

Svejnar, J. (1986), Bargaining Power, Fear of Disagreement, and Wage Settlements: Theory and Evidence from U.S. Industry, Econometrica, vol. 55, 1055-1078.

Windmeijer, F. (2005), A finite sample correction for the variance of linear efficient two-step GMM estimators, Journal of Econometrics, vol. 126, 25-51. 
Internet source:

http:/www.worker-participation.eu/National-Industrial-Relations/Across-Europe/Boardlevel-Representation2: Board-Level Representation (accessed July 20, 2015) 


